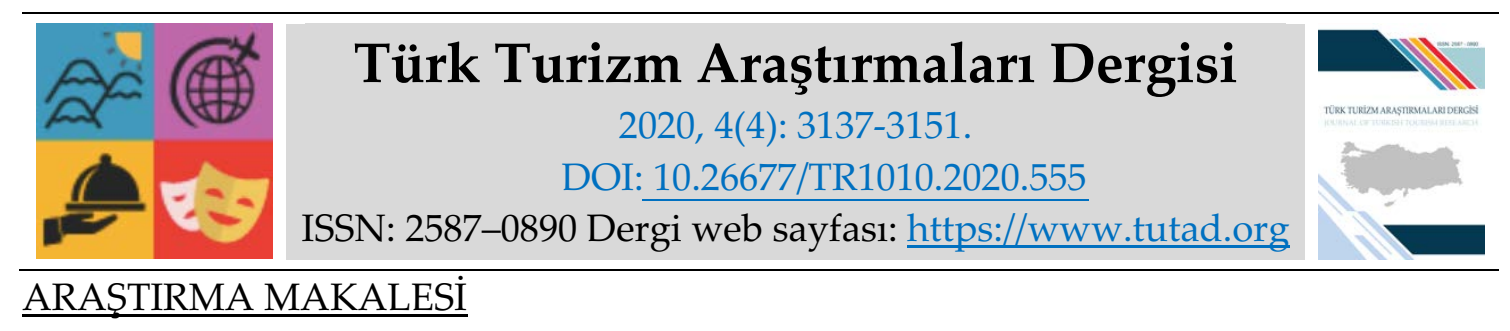

\title{
Yaşam Tarzının Kahve Dükkânlarını Tercih Etme Niyeti Üzerine Etkisinin İncelenmesi
}

Arş. Gör. Bahar BAYINDIR, Kırklareli Üniversitesi, Turizm Fakültesi, Kırklareli, e-posta: baharbayindir7@gmail.com

ORCID: https://orcid.org/0000-0002-6440-1132

Doç. Dr. Hilmi Rafet YÜNCÜ, Anadolu Üniversitesi, Turizm Fakültesi, Eskişehir, e-posta: hryuncu@anadolu.edu.tr

ORCID: https://orcid.org/0000-0002-2876-004X

Öz

Günümüz tüketicilerinin yaşam tarzlarındaki değişimler tüketim şekillerini etkilemektedir. Bu çalışmanın temel amacı yaşam tarzının kahve dükkanlarını tercih etme niyeti üzerinde etkisinin olup olmadığını incelemektir. Bu amaç doğrultusunda anket tekniğiyle 390 katılımcıya anket uygulanmıştır. Elde edilen veriler ile gerçekleştirilen analizler sonucunda katılımcıların kahve dükkanlarına haftada 1-2 defa gittiği ve kahve dükkanı türü olarak genellikle yerli kahve dükkanlarını tercih ettiği, kahve dükkanlarını tercih ederken kahve dükkanlarında sırasıyla arkadaşlarla buluşma, aileyle vakit geçirme ve yeme içme gereksinimlerini karşılamaya önem verdiği görülmüştür. Çalışmanın temel amacı doğrultusunda gerçekleştirilen regresyon analizi sonucunda da yaşam tarzı değişkenlerinin kahve dükkanlarını tercih etme niyeti üzerinde anlamlı bir etki gösterdiği görülmüştür. Yaşam tarzına yönelik değişkenler incelendiğinde moda tutkunları ve yeniliğe açık olanların niyeti pozitif yönde açıkladığı becerikliler, ilgi alanı sınırlı olanlar ve inananların ise niyeti negatif yönde açıkladığı saptanmıştır.

Anahtar Kelimeler: Yaşam Tarzı, Kahve, Kahve Dükkanı, Niyet, Kahve Dükkanı Tercih Etme Niyeti.

Makale Gönderme Tarihi: 09.06.2020

Makale Kabul Tarihi: 10.10 .2020

\section{Önerilen Atıf:}

Bayındır, B. ve Yüncü, H. R. (2020). Yaşam Tarzının Kahve Dükkânlarını Tercih Etme Niyeti Üzerine Etkisinin İncelenmesi, Türk Turizm Araştırmaları Dergisi, 4(4): 3137-3151.

(C) 2020 Türk Turizm Araştırmaları Dergisi. 


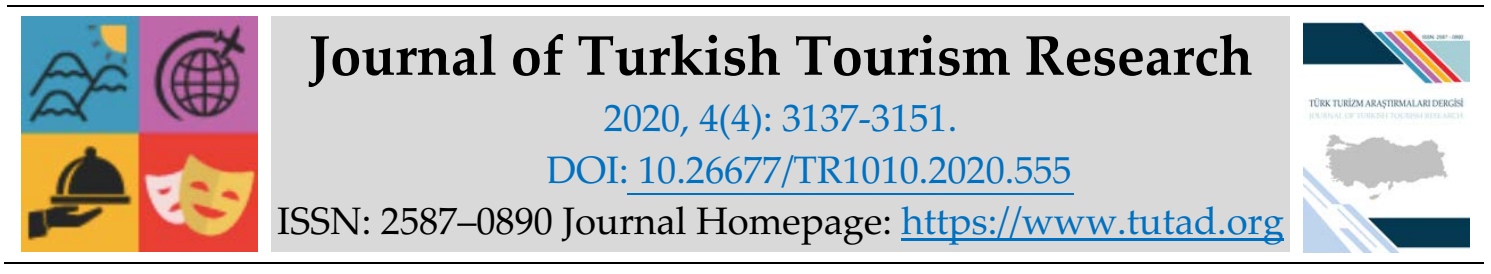

\title{
$\underline{\text { RESEARCH PAPER }}$
}

\section{Investigating the Effect of Lifestyle on The Intention to Choose Coffee Shop}

Research Assistant Bahar BAYINDIR, Kırklareli University, Faculty of Tourism, Kırklareli, email: baharbayindir7@gmail.com ORCID: https://orcid.org/0000-0002-6440-1132

Associate Prof. Dr. Hilmi Rafet YÜNCÜ, Anadolu University, Faculty of Tourism, Eskişehir, email: hryuncu@anadolu.edu.tr

ORCID: https://orcid.org/0000-0002-2876-004X

\begin{abstract}
Changes in lifestyle of today's consumers affect their consumption patterns. The main purpose of this study is to examine whether lifestyle has an effect on the intention of choosing coffee shops. For this purpose, a survey was applied to 390 participants using the survey technique. As a result of the analysis made with the data obtained, it was observed that the participants went to coffee shops 1-2 times a week and generally preferred domestic coffee shops as the type of coffee shop, while choosing coffee shops, it was important to meet friends, spend time with the family and meet their eating and drinking needs respectively. As a result of the regression analysis conducted in line with the main purpose of the study, it was observed that lifestyle variables had a significant effect on intention to choose coffee shop. When the variables related to lifestyle were analyzed, it was found that those who are fashion lovers and those who are open to innovation affect the intention in a positive way, those with limited interest and believers negatively affect the intention.
\end{abstract}

Keywords: Lifestyle, Coffee, Coffee Shop, Intention, Intention to Choose Coffee Shop.

Received: 09.06.2020

Accepted: 10.10 .2020

\section{Suggested Citation:}

Bayındır, B. and Yüncü, H. R. (2020). Investigating the Effect of Lifestyle on The Intention to Choose Coffee Shop, Journal of Turkish Tourism Research, 4(4): 3137-3151.

(C) 2020 Türk Turizm Araştırmaları Dergisi. 


\section{Gíriş}

Dünyanın en popüler içeceklerden biri olan kahve (Spence ve Carvalho, 2020), on altıncı yüzyılın ortalarından beri tüketici kültüründe önemli bir role sahip olmaktadır (Samoggia ve Riedel, 2018). Tüm dünyada günlük olarak tüketilen kahve, günümüzde popüler hale gelerek sosyal yaşamın ayrılmaz bir parçası haline gelmiştir (Hu ve Lee, 2019; Yılmaz vd., 2017). Son yıllarda kahvenin, "üçüncü dalga kahve tüketimi" olarak adlandırılması ve nitelikli bir ürün olarak görülmesi kahve kültüründe önemli değişimler meydana getirmiştir (Manzo, 2014). Ancak bu değişik kahve kültürünün oluşmasında ve kahvenin daha popüler bir hale gelmesinde kahve dükkanları (bazı ülkelerde kafe veya kahvehane olarak da bilinir) olarak nitelendirilen mekanların da büyük bir önemi bulunmaktadır (Tuker, 2011).

Tüm dünyada milyonlarca insan her gün yüz milyonlarca fincan kahve tüketmektedir. Modern kafeler olarak adlandırılan kahve dükkanlarında kahve tüketimi şehirlerde günlük yaşam deneyimi içerisinde gerekli olmaya başlamıştır (Bookman, 2014). Ancak kamusal mekan olma özelliği taşıyan bu mekanlar, sadece bir fincan kahve tüketmenin ötesinde tüketicilerin farklı yönlerden edinebileceği deneyimler de sağlayabilmektedir. Tüketiciler kahve dükkanlarında sunulan ürün ve hizmeti satın almakta, akranlarıyla ve aileleriyle sosyalleşmekte veya kişisel deneyim gibi farklı yönlerden deneyimler edinebilmektedir (Bayındır ve Önçel, 2019; Huang, 2017; Manzo, 2014).

Tüketim alışkanlıkları bireylerin yaşam tarzlarına göre farklılıklar gösterebilmektedir. Yaşam tarzı, tüketicilerin davranışları ve tercihleri üzerinde büyük bir etkiye sahip olmaktadır (Cătălin ve Andreea, 2014). Sosyal bilimlerde sıklıkla kullanılan ve kabul edilen bir kavram olan yaşam tarzı, bireyleri birbirinden ayıran, nasıl bir yaşam sürdüklerini ve yaşamlarında neye değer verdiklerini kapsayan bir kavramdır (Acher, 2017). Kahve dükkanlarında yaşanan deneyimler de tüketiciler arasında farklılık göstermektedir. Aşık (2017) kahve tüketiminin, tüketicilerin cinsiyet, yaş, meslek, gelir düzeyi gibi bazı değişkenlere göre farklılık gösterdiğini belirtirken, Limón vd. (2017) tüketicilerin yaşam tarzlarına göre de farklı kahve tüketim alışkanlıkları gösterdiğini belirtmektedir.

Dedeoğlu ve Üstündağlı (2011) tüketicilerin tercihlerinin, ilgilerinin ve fikirlerinin belli bir yaşam tarzının yansıması olduğunu belirtmektedir. Tüketicilerin satın alma davranışları hakkında bilgi almak ve tüketicinin bir ürünü niçin satın aldığının cevabını öğrenmek için tüketicilerin yaşam tarzının belirlenmesi büyük önem arz etmektedir (Hamşığlu, 2013). Aynı eğitim ve gelir seviyesine sahip tüketicilerin bakış açıları farklı olabilir ve tüketimlerinde de farklılıklar oluşabilir. Bu nedenle temel problem tüketicilerin tüketim davranışlarının ve nedenlerinin yaşam tarzlarına göre değişebilmesidir (Bulut, 2019). Bu açıdan incelendiğinde; kahve dükkanlarına gitmeyi kendilerini ifade etme biçimi ve toplumsal yaşamda bir statü göstergesi olarak algilayan tüketicilerin kahve dükkanlarını tercih etme niyetinin yaşam tarzına göre farklılık gösterdiği düşünülmektedir.

Tüketicilerin yaşam tarzının kahve dükkanlarını tercih etme niyeti üzerine etkisinin olup olmadığını incelemek bu çalışmanın amacını oluşturmaktadır. Yaşam tarzlarına göre kahve dükkanlarını tercih etme niyeti konusu dikkate alınarak gerçekleştirilen literatür incelemesinde benzer çalışma konusunu ele alan çalışmaya rastlanamamıştır. Bu açıdan bakıldığında kahve dükkanlarını tercih etme niyetinin yaşam tarzlarına göre farklılık gösterip göstermediğinin incelenmesinin önemli olduğu düşünülmektedir. 


\section{KAVRAMSAL ÇERÇEVE}

Yüzyıllardır günlük hayatın ve kültürün vazgeçilmez bir parçası olan kahve (Feria-Morales, 2002), günümüzde ticari ve sosyal açıdan büyük önem taşımaktadır (Özdestan, 2014). Her gün, tüm dünyada milyonlarca insan yüz milyonlarca fincan kahve tüketmektedir (Shaker ve Rath, 2019). Kahvenin artan önemi ve tüketimi nedeniyle kahve dükkanlarında kahve içme kültürü ortaya çıkmıştır (Tan ve Lo, 2008). Günümüzde şehirlerdeki yaşam hızının geçmişe göre daha hızlı devam etmesi nedeniyle evleri ile işleri arasında gidip gelen insanlar; sosyal gereksinimlerini karşılayabilen, rahatlatıcı üçüncü bir mekâna ihtiyaç duymaktadır (Oldenburg, 1989; Uygun, 2016; Bayındır, 2019). Kahve dükkanları da ev ve işyerlerine alternatif olarak insanların sosyalleşebileceği ve rahatlayabileceği mekanların başında gelmektedir. Birçok kahve çeşidinin satıldığı, hazırlandığı, servis edildiği ve içildiği kahve dükkanları, insanların ekonomik bir şekilde sosyalleşebileceği mekanlar olarak şehir merkezlerinde önemli bir yere sahip olmaktadır (Tucker, 2011).

Dünya çapında çarpıcı bir şekilde büyüme gösteren kahve dükkanları yiyecek-içecek hizmet endüstrisine hâkim olduğu görülmektedir (Wei vd., 2019). Son yıllarda kahve dükkanları Türkiye'deki yiyecek içecek hizmetleri endüstrisinin de önemli bir parçası haline gelmiştir. Özellikle Starbucks gibi yabancı kahve dükkanı sayısı büyük ölçüde artış göstermiş ve Türkiye'de çok sayıda benzersiz ve özel kahve dükkanları açılmıştır. Türkiye'de sayıları artan yerli ve yabancı kahve dükkanlarını tercih eden tüketiciler için önemli olan yalnızca kahve içmek değil aynı zamanda rahat bir ortamda bulunmak, arkadaşlarla vakit geçirmek ve kahve yanın ürünlerini tüketmek önemli olmaya başlamıştır.

Lee ve Yeu (2010) kahve dükkanlarını tercih eden tüketicilerin yaşının, statüsün, kültürel değerlerinin ve yaşam tarzının kahve dükkanı tercihini etkilediğini belirtmektedir. Akarçay (2014) yerli ve yabancı kahve dükkanlarına yönelik çalışmasında kahve dükkanlarının tüketicilere göreceli bir özgürlük alanı sunduğundan bahsetmektedir. Aynı zamanda, kahve dükkanlarına giden tüketicilerin yaşam tarzına uygun içecekleri tamamen kendi isteklerine göre tercih ettiği belirtilmektedir. Brewer (2015) ise çalışmasında kahve dükkanlarının farklı demografik özelliklere ve farklı yaşam tarzlarına hitap ettiğini belirtmektedir.

Yaşam tarzı tüketicilerin satın alma davranışlarını etkileyen en önemli faktörlerden birisidir (Kabakçı ve Madran, 2002). Bireyleri birbirinden ayıran, nasıl yaşam sürdüklerini ve yaşamları boyunca neye değer verdiklerini kapsayan bir kavram olan yaşam tarzı (Özgen ve Yeşiloğlu, 2015); insanların boş zamanlarını nasıl harcadığını, sahip oldukları ilgi alanlarını, çevresinde nelere önem verdiğini, dünya ve kendi hakkındaki düşüncelerini içeren bir yaşama biçimi olarak tanımlanmaktadır (İslamoğlu ve Altunışık, 2013; Khraim, 2015).

Yaşam tarzının temel amacı tüketicileri daha iyi bir şekilde tanımlamak, tüketicilerin istek veya ihtiyaçlarını tatmin etmek ve bu doğrultuda tüketicilerle iletişim kurup ürün veya hizmeti onlara pazarlamaktır. Bu noktada, tüketicilerin yaşam tarzlarını ortaya çıkarabilmek amacıyla pek çok yöntem geliştirilmiştir. Faaliyetler, İlgi Alanları ve Fikirler (Activities, Interests and OpinionsAIO), Rokeach Değerler Sistemi (Rokeach Value Survey RVS), Değerler Listesi (List of Value LOV), Değerler ve Yaşam Tarzları (Value and Lifestyles VALS), Değerler ve Yaşam Tarzları2 (VALS2) yöntem olarak kullanılmaktadır. VALS2, temeli Maslow'un ihtiyaçlar hiyerarşisine dayanan, tüketicilerin davranışlarını daha iyi tespit etmek amacıyla VALS yönteminin geliştirilerek günümüze uyarlanmış halidir (Hamşıŏlu, 2013).

Geliştirilen VALS2 ölçeği ile birlikte yaşam tarzı değişkenleri de belirlenmiştir. Bu çalışmada dikkate alınan yaşam tarzları değişkenleri moda tutkunları, yenilikçiler, becerikliler, ilgi alanı kısıtlı olanlar ve inananlar değişkenleridir. Moda tutkunları genellikle moda ürünlere, eğlenceye meraklı olup imaj bilinçli bireylerden oluşmaktadır. Yenilikçiler, yeni fikirler ve 
teknolojiler hakkında bilgi sahibi olan, meraklı ve aktif bireyler olarak belirtilmektedir. Becerikliler, el becerisi gerektiren ve kullanabileceği şeyleri genellikle kendi yapmayı seven, hazır ürün satın almaktansa onu yapmayı tercih eden bireylerdir. İnananlar; dine, aileye ve toplumsal değerlere önem veren, gerekmedikçe harcama yapmayan, muhafazakar bireylerdir. İlgi alanı kısıtlı olanlar ise hobi edinmeyi sevmeyen, içe kapanık, kendi halinde yaşamayı isteyen, az şeyle ilgilenen bireyler olarak belirtilmektedir (Bulut, 2019).

Gastronomi çalışmalarında yaşam tarzı aracılığıyla pek çok soruya cevap aranmaya çalışıldığı görülmektedir. Bu çalışmalar; gastronomi turistlerinin hedonik tüketim ve gönüllü sade yaşam tarzı davranışlarını ortaya çıkarma (Demir, 2019), fast food ürünleri satın alan tüketicilerin yaşam tarzlarını belirleme (Hamşığlu, 2013), tüketicilerin yiyecek tercihlerini yaşam tarzına göre pazar bölümlendirilmesi (Kesic ve Piri-Rajh, 2003; Ryan vd., 2008), organik gıda müşterilerinin tüketim davranışlarının yaşam tarzı değişkeni çerçevesinde incelenmesi (Özgen ve Yeşiloğlu, 2015), şarapla ilgili yaşam tarzının pazar bölümlendirilmesi (Bruwer ve Li, 2007), yaşam tarzı ve yiyecek içecek tercihleri arasındaki ilişkinin incelenmesidir (Saçllık, 2017). Kahve veya kahve dükkanları çalışmaları incelendiğinde ise çok fazla çalışmaya rastlanamamıştır. Limon ve diğerlerinin (2017) kahve tüketim alışkanlıkları ile yaşam tarzı arasında ki ilişkiyi inceledikleri çalışmalarında bu iki değişken arasında ilişki olduğu tespit edilmiştir. Bu doğrultuda bu çalışma ile farklı yaşam tarzlarına sahip tüketicilerin kahve dükkanlarını tercih etme niyetleri incelenecektir.

\section{ARAŞTIRMA YÖNTEMI}

Araştırmanın amacı yaşam tarzının kahve dükkanlarını tercih etme niyeti üzerine etkisinin olup olmadığını incelemektir. Bu amaç çerçevesinde bağımsız değişkenlerin bağımlı değişken olan kahve dükkanlarını tercih etme niyeti üzerinde anlamlı bir etkisi olup olmadığını anlamak amacıyla hipotezler ve araştırma modeli oluşturulmuştur. Ortaya çıkan araştırma modeli Şekil 1 'de gösterilmiştir.

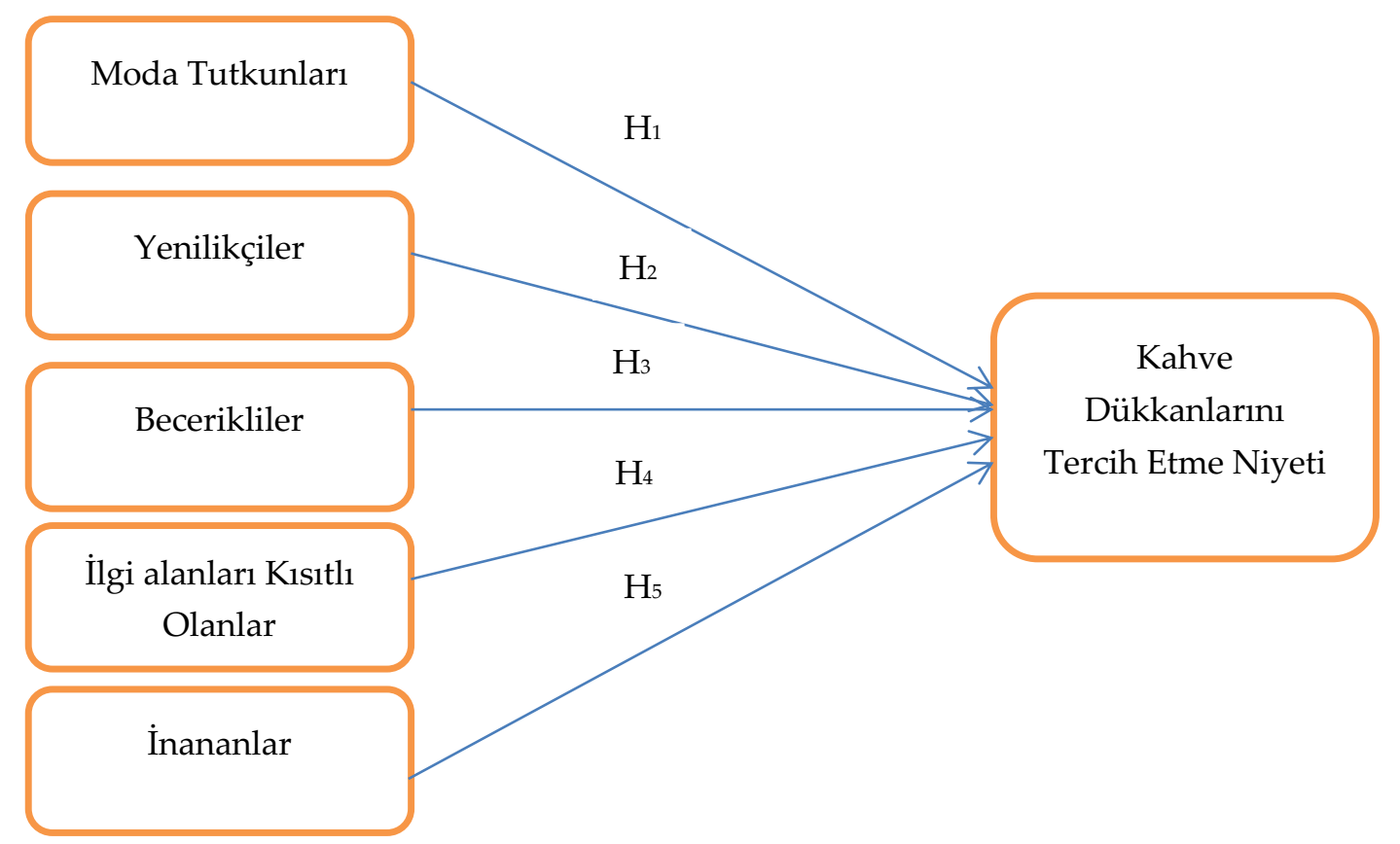

Şekil 1: Araştırma Modeli 
$H$ : Yaşam tarzının kahve dükkanlarını tercih etme niyetine anlamlı bir etkisi vardır.

H1: Moda tutkunlarının kahve dükkanlarını tercih etme niyetine anlamlı bir etkisi vardır.

$H_{2:}$ Yenilikçilerin kahve dükkanlarını tercih etme niyetine anlamlı bir etkisi vardır.

H3: Beceriklilerin kahve dükkanların tercih etme niyetine anlamlı bir etkisi vardır.

H4: İlgi alanı kısıtlı olanların kahve dükkanların tercih etme niyetine anlamlı bir etkisi vardır.

H5: Inananların kahve dükkanların tercih etme niyetine anlamlı bir etkisi vardır.

Belirtilen hipotezlerde; yaşam tarzı değişkenlerinden moda tutkunu, yenilikçiler, becerikliler, ilgi alanı kısıtlı olanlar ve inananların kahve dükkanlarını tercih etme niyetine etkisini ortaya çıkarmak amaçlanmıştır.

Araştırmanın verilerinin toplanması ve yorumlanmasında nicel araştırma yönteminden yararlanılmıştır. Nicel araştırma yöntemlerinden anket tekniğinden yararlanılarak araştırma amacına uygun olacak şekilde veri elde edilmeye çalışılmıştır. Araştırma konusuyla ile ilgili daha önce kullanılmış ölçekler incelenmiştir. İncelemeler sonucunda tüketicilerin yaşam tarzlarını ortaya çıkarabilmek amacıyla VALS2 ölçeği kullanılmıştır. Bu ölçek daha önce birçok araştırmada kullanılmış olup geçerliği ve güvenirliği test edilmiştir (Hamşığlu, 2013; Özdemir, 2013; Yıldırım, 2016). Tüketicilerin kahve dükkanlarını tercih etme niyetini ortaya çıkabilmek amacıyla daha önce geçerliği ve güvenirliği test edilmiş olan Bayındır'ın (2018) kahve dükkanlarında kahve içme niyetine ilişkin ölçeği kullanılmıştır.

Araştırmanın evrenini kahve dükkanlarında kahve içen tüketiciler oluşturmaktadır. Araştırma evrenine ulaşmanın maliyetli olması ve zaman sınırı bulunması sebebiyle araştırma amacına uygun olacak şekilde araştırma örneklemi oluşturulmuştur. Anket formu araştırmanın amacına uygun olacak şekilde İstanbul'un belirli bir bölgesinde bulunan kahve dükkanlarındaki tüketicilere uygulanmak istenmiştir. Ancak kahve dükkanı yöneticileri müşterilerin bu durumdan rahatsız olabileceklerini öngörerek anketin kahve dükkanlarında uygulanmasını kabul etmemiştir. Bu sebeple anketler kolayda örnekleme yöntemiyle İstanbul'un işlek caddelerinden biri olan İstiklal Caddesi'nde 25 Kasım-15 Aralık 2019 tarih aralığında katılımcılara uygulanmıştır. Veri toplama süreci 402 katılımcıyla ile yüz yüze görüşülerek gerçekleştirilmiştir. Ancak 12 anket formu eksik ve hatalı işaretlendiği için araştırma analizlerine dahil edilmemiştir.

Katılımcıların demografik özelliklerini ortaya çıkarabilmek amacıyla frekans ve yüzde dağılımlarına bakılmıştır. Kahve dükkanlarında kahve içme alışkanlıklarına ilişkin ifadeler değerlendirilirken de frekans ve yüzde dağılımlarından faydalanılmıştır. Yaşam tarzı değişkenlerinin ortaya çıkarmak ve araştırma modelini test etmek amacıyla korelasyon ve regresyon analizi gerçekleştirilmiştir.

\section{BULGULAR}

Katılımcların cinsiyeti, medeni durumu, yaşı, eğitim durumu ve aylık geliri sorularına ilişkin frekans ve yüzde analizlerinin bulguları Tablo $1^{\prime}$ de verilmiştir. Katılımcıların \%52,8'i kadınlardan oluşmaktadır. Medeni durum incelendiğinde katılımcıların \%60,5'inin bekar olduğu görülmektedir. Yaş grup dağılımında 18-23 yaş gruplarının, toplam katılımcıların \%39,2'sini oluşturduğu görülmektedir. Eğitim durumu incelendiğinde katılımcların $\% 40,3$ 'ünün lisans düzeyinde olduğu görülmektedir. Aylık gelir durumunda ise \%30,5'inin aylık 1500 TL'den az 
gelir ettiği, aylık 6000 TL'den fazla gelire sahip katılımclların toplam katılımcıların \%16,4'ünü oluşturduğu görülmektedir.

Tablo 1. Katılımcıların Demografik Özelliklerine İlişkin Bulgular

\begin{tabular}{|c|c|c|}
\hline Cinsiyet & $\mathbf{n}$ & $\%$ \\
\hline Kadın & 206 & 52,8 \\
\hline Erkek & 184 & 47,2 \\
\hline Toplam & 390 & 100 \\
\hline Medeni Durum & $\mathbf{n}$ & $\%$ \\
\hline Bekar & 236 & 60,5 \\
\hline Evli & 154 & 39,5 \\
\hline Toplam & 390 & 100 \\
\hline Yaş & $\mathbf{n}$ & $\%$ \\
\hline $18-23$ & 153 & 39,2 \\
\hline $24-29$ & 85 & 21,8 \\
\hline $30-35$ & 55 & 14,1 \\
\hline $36-41$ & 45 & 11,5 \\
\hline $42-47$ & 28 & 7,2 \\
\hline 47 ve üzeri & 24 & 6,2 \\
\hline Toplam & 390 & 100 \\
\hline Eğitim Durumu & $\mathrm{n}$ & $\%$ \\
\hline İlkokul & 51 & 13,1 \\
\hline Ortaokul & 23 & 5,9 \\
\hline Lise & 78 & 20 \\
\hline Ön lisans & 43 & 11 \\
\hline Lisans & 157 & 40,3 \\
\hline Lisansüstü & 38 & 9,7 \\
\hline Toplam & 390 & 100 \\
\hline Aylık Gelir Durumu & $n$ & $\%$ \\
\hline 1500 TL'den az & 119 & 30,5 \\
\hline $1500-3000 \mathrm{TL}$ & 103 & 26,4 \\
\hline $3001-4500 \mathrm{TL}$ & 92 & 23,6 \\
\hline 4501-6000 TL & 51 & 13,1 \\
\hline 6000 TL'den fazla & 25 & 16,4 \\
\hline Toplam & 390 & 100 \\
\hline
\end{tabular}

Katılımcıların kahve dükkanlarına gitme sıklıklarını, genellikle tercih ettikleri kahve dükkanı türünü tespit etmek amacıyla sorulan sorulara ilişkin analizler Tablo 2'de bulunmaktadır. Katılımcıların \%43,8'inin kahve dükkanlarına haftada 1-2 defa gittiği ve \%53,6'sının yerli kahve dükkanları tercih ettiği görülmektedir.

Tablo 3'te katılımcıların kahve dükkanlarında tercih ettikleri içecek türlerinin dağılımı verilmiştir. Katılımcılar kahve dükkanlarında genellikle tercih edilen içecek türü sorusunda bulunan ifadelere birden fazla cevap vermişlerdir. Tablo 3'e göre Türk kahvesi veya türevlerini 271, espresso ve espresso bazlı içecekleri 252 ve kahve dükkanlarında çay tercih edenlerin sayısı ise 213 'dür. 
Tablo 2. Katılımcların Kahve Dükkanlarını Tercih Etme Alışkanlıklarına İlişkin Bulgular

\begin{tabular}{lcc}
\hline Kahve Dükkanlarına Gitme Sıklı̆̆1 & $\mathbf{n}$ & $\mathbf{\%}$ \\
\hline Ayda 1 defa & 115 & 29,5 \\
Haftada 1-2 defa & 171 & 43,8 \\
Haftada 3-4 defa & 75 & 19,2 \\
Günde 1 veya daha fazla & 29 & 7,4 \\
Toplam & 390 & 100 \\
\hline Tercih edilen Kahve Dükkanı & $\mathbf{n}$ & $\mathbf{\%}$ \\
\hline Yerli kahve dükkanı & 205 & 52,6 \\
Yabancı kahve dükkanı & 185 & 47,4 \\
Toplam & 390 & 100 \\
\hline
\end{tabular}

Tablo 3. Katılımcıların Kahve Dükkanlarında Tercih Ettiği İçecek Türüne İlişkin Bulgular

\begin{tabular}{lcc}
\hline & $\mathbf{n}$ & $\mathbf{\%}$ \\
\hline Türk kahvesi veya türevleri & 271 & 29,7 \\
Espresso veya espresso bazlı içecekler & 252 & 27,6 \\
Çay çeşitleri & 213 & 23,3 \\
Hazır(granül) kahve & 109 & 11,9 \\
Yeni nesil demleme yöntemiyle hazırlanan filtre kahveler & 68 & 7,4 \\
Toplam & $913^{*}$ & 100 \\
\hline
\end{tabular}

*Çoklu yanıt olduğu için $n$ sayısı örneklem hacmini geçmektedir.

Tablo 4'te katılımcıların kahve dükkanını tercih etme nedenlere ilişkin ortalama ve standart sapmalar gösterilmektedir. Tablo 4'e göre kahve dükkanını tercih eden katılımcılar için arkadaşlarla buluşmak en önemli neden iken kahve dükkanlarında kitap okumak veya ders çalışmak büyük bir öneme sahip olmamaktadır.

Tablo 4. Katılımcıların Kahve Dükkanlarını Tercih Etmesindeki Nedenlere İlişkin Bulgular

\begin{tabular}{lcc}
\hline & Ortalama & $\begin{array}{c}\text { Standart } \\
\text { Sapma }\end{array}$ \\
\hline Arkadaşlarla buluşmak & 3,94 & 1,12 \\
Aileyle vakit geçirmek & 3,35 & 1,38 \\
Yeme-içme gereksinimi karşılamak & 3,14 & 1,26 \\
Dinlenmek & 3,02 & 1,18 \\
Sosyal medyada paylaşım yapmak & 2,55 & 1,44 \\
Yeni insanlarla tanışmak (arkadaş edinmek) & 2,19 & 1,29 \\
Kitap okumak/Ders çalışmak & 1,84 & 1,19 \\
\hline
\end{tabular}

Ölçme aracının güvenirliğini, geçerliğini test etmek ve soru maddelerinin kaç faktöre dağıldığını tespit etmek amacıyla açıklayıcı faktör analizi (AFA) faydalanılmıştır. İlk aşamada 35 ifade ile gerçekleştirilen analizde 3 ifade güvenirliği olumsuz yönde etkilemesi, 4 ifade faktör yüklerinin birden fazla boyuta düşük farkla dağılması ve 3 ifade ise faktör yüklerinin düşük olması nedeniyle analizden çıkarılmıştır. İfadelerin analizden çıkarılması sonucunda elde edilen yirmi beş ifade ile Varimax döndürme yöntemiyle tekrar faktör analizi gerçekleştirilmiştir. Gerçekleştirilen analiz sonucunda özdeğeri 1'den büyük olan yaşam tarzına ilişkin beş, kahve dükkanlarını tercih etme niyetine ilişkin bir boyut ortaya çıkmıştır. Ortaya çıkan faktörler toplam varyansın \%66,99'unu açıladığı görülmektedir. 
Tablo 5. Faktör Analizine İlişkin Bulgular

\begin{tabular}{|c|c|c|c|c|c|c|}
\hline & 1 & 2 & 3 & 4 & 5 & 6 \\
\hline $\begin{array}{l}\text { 1.Kahve dükkanlarına gitmeyi arkadaşlarıma } \\
\text { ya da başkalarına tavsiye edebilirim. }\end{array}$ & 0,88 & & & & & \\
\hline $\begin{array}{l}\text { 2.Başkalarına kahve dükkanları hakkında } \\
\text { olumlu şeyler söyleyebilirim. }\end{array}$ & 0,86 & & & & & \\
\hline $\begin{array}{l}\text { 3.Gelecekte kahve dükkanlarına gitme } \\
\text { sıklığımı arttırmayı düşünüyorum. }\end{array}$ & 0,80 & & & & & \\
\hline $\begin{array}{l}\text { 4.Yakın zamanda kahve dükkanlarına } \\
\text { gitmeyi planlıyorum. }\end{array}$ & 0,75 & & & & & \\
\hline $\begin{array}{l}\text { 5. Yakın zamanda kahve dükkanlarına kahve } \\
\text { içmeye hazırım. }\end{array}$ & 0,70 & & & & & \\
\hline $\begin{array}{l}\text { 6.Birçok insana göre modaya daha uygun } \\
\text { giyinirim. }\end{array}$ & & 0,807 & & & & \\
\hline 7.En son modaya uygun giyinmeyi severim. & & 0,791 & & & & \\
\hline $\begin{array}{l}\text { 8.Çoğu insandan daha fazla modaya uygun } \\
\text { giyinirim. }\end{array}$ & & 0,698 & & & & \\
\hline 9.Gösterişten hoşlandığımı itiraf etmeliyim. & & 0,684 & & & & \\
\hline $\begin{array}{l}\text { 10.Modayı takip eden biri olarak tanınmak } \\
\text { isterim. }\end{array}$ & & 0,658 & & & & \\
\hline 11.En son modayı ve yenilikleri takip ederim. & & 0,602 & & & & \\
\hline $\begin{array}{l}\text { 12.Daha önce denenmemiş şeyleri denemek } \\
\text { isterim. }\end{array}$ & & & 0,769 & & & \\
\hline $\begin{array}{l}\text { 13. Hayatımda genellikle heyecan olmasından } \\
\text { hoşlanırım. }\end{array}$ & & & 0,762 & & & \\
\hline $\begin{array}{l}\text { 14.Daha önce yapmadığım bir şeyi yapmaya } \\
\text { kalkışmaktan hoşlanırım. }\end{array}$ & & & 0,683 & & & \\
\hline $\begin{array}{l}\text { 15. Hiçbir zaman işe yaramayacak bile olsa } \\
\text { öğrenmek isterim. }\end{array}$ & & & 0,639 & & & \\
\hline 16. Çoğu zaman heyecan ararım & & & 0,624 & & & \\
\hline 17. Yeni şeyler denemeyi severim. & & & 0,566 & & & \\
\hline $\begin{array}{l}\text { 18. Bir yıl veya daha fazla zamanımı yabancı } \\
\text { ülkede geçirmek isterim. }\end{array}$ & & & 0,529 & & & \\
\hline
\end{tabular}

\begin{tabular}{|c|c|c|c|c|c|c|}
\hline 19. Elişleriyle uğraşmayı severim. & & & & 0,793 & & \\
\hline $\begin{array}{l}\text { 20.El becerimi kullanarak, yararlanabileceğim } \\
\text { ürünler üretmekten hoşlanırım. }\end{array}$ & & & & 0,772 & & \\
\hline $\begin{array}{l}\text { 21. Satın almaktansa, onları yapmayı tercih } \\
\text { ederim. }\end{array}$ & & & & 0,729 & & \\
\hline 22. Kabul etmeliyim ki, ilgi alanlarım sınırlı. & & & & & 0,780 & \\
\hline 23. Yok denecek kadar az şeyle ilgiliyim. & & & & & 0,771 & \\
\hline $\begin{array}{l}\text { 24. Devlet okullarında dini eğitim teşvik } \\
\text { edilmeli }\end{array}$ & & & & & & 0,738 \\
\hline 25. Kutsal kitaplara inanırım. & & & & & & 0,671 \\
\hline Ortalama & 3,60 & 3,05 & 3,84 & 3,26 & 2,81 & 3,30 \\
\hline Açıklanan varyans & 28,75 & 8,61 & 10,50 & 7,59 & 4,69 & 5,89 \\
\hline Cronbach Alpha & 0,89 & 0,84 & 0,81 & 0,74 & 0,63 & 0,71 \\
\hline
\end{tabular}

Toplam varyans açıklama oranı: \%66,05; KMO: 0,79; Bartlett's Test of Sphericity: 0,000.

(1: Niyet, 2: Moda Tutkunları, 3: Yenilikçiler, 4: Becerikliler, 5: İlgi Alanları Sınırlı Olanlar, 6: İnananlar) 
Tablo 5'te yaşam tarzına ve kahve dükkanlarını tercih etme niyetine yönelik gerçekleştirin faktör analizine ilişkin bulgular verilmiştir. Yaşam tarzına ait boyutlar literatür ile paralel olarak "moda tutkunları", "yeniliğe açı olanlar", "becerikliler", "ilgi alanları sınırlı olanlar" ve "inananlar" olarak isimlendirilmiştir. Ayrıca ölçme aracının bütününe ilişkin yirmi beş ifade ile gerçekleştirilen güvenirlik analizi sonucunda Cronbach's Alpha katsayı değeri 0,74 olarak hesaplanmıştır. Bu değer tavsiye edilen asgari değerlerin üzerinde olması, ölçme aracının geçerlik ve güvenirlik kıstaslarını sağladığını göstermektedir. Aynı zamanda, faktör analizi gerçekleştirildikten sonra ortaya çıan faktörlerin Cronbach's Alpha katsayı değeri Tablo 5'de gösterilmektedir.

Kahve dükkanlarını tercih etme niyeti üzerinde yaşam tarzının etkisini incelemek amacıyla regresyon analizi gerçekleştirilmiştir. Ancak regresyon gerçekleştirilmeden önce değişkenler arasında ilişki olup olmadığını ortaya çıkarabilmek amacıyla korelasyon analizi gerçekleştirmiştir. Değişkenler arasındaki ilişkiyi ortaya çıkarabilmek amacıyla gerçekleştirilen Pearson korelasyon analizine ilişkin bilgiler Tablo 6'da belirtilmiştir.

Tablo 6. Değişkenler Arası İlişkiler

\begin{tabular}{lcccccccc}
\hline & Ort & SS & $\mathbf{1}$ & $\mathbf{2}$ & $\mathbf{3}$ & $\mathbf{4}$ & $\mathbf{5}$ & $\mathbf{6}$ \\
\hline 1.Moda Tutkunları & 2,82 & 1,03 & 1 & & & & & \\
2. Yenilikçiler & 3,84 & 0,84 & $0,43^{*}$ & 1 & & & & \\
3. Becerikliler & 3,26 & 1,17 & $-0,37^{*}$ & $-0,26^{*}$ & 1 & & & \\
4. İlgi alanları sinırlı olanlar & 2,81 & 1,14 & $-0,28^{*}$ & $-0,21^{*}$ & $-0,15^{*}$ & 1 & & \\
5. İnananlar & 3,30 & 1,34 & $-0,40^{*}$ & $-0,32^{*}$ & $0,34^{*}$ & $0,33^{*}$ & 1 & \\
6. Niyet & 3,60 & 1,06 & $0,34^{*}$ & $0,36^{*}$ & $-0,34^{*}$ & $-0,24^{*}$ & $-0,31^{*}$ & 1 \\
\hline
\end{tabular}

${ }^{*} \mathrm{p}<0,01$

Pearson korelasyon analizi sonuçlarına göre kahve dükkanlarını tercih etme niyeti ile yaşam tarzı bağımsız değişkenleri arasında moda tutkunları $(r=0,34 ; \mathrm{p}<0,01)$ ve yenilikçiler için $(r=0,36$; $\mathrm{p}<0,01)$ pozitif yönlü ve anlamlı bir ilişki bulunmaktadır. Ayrıca becerikliler $(r=-0,34 ; p<0,01)$, ilgi alanı sınırlı olanlar $(r=-0,24 ; p<0,01)$ ve inanlar $(r=-0,31 ; p<0,01)$ değişkenleri ile negatif yönlü ve anlamlı bir ilişki bulunmaktadır. Bu doğrultuda bağımsız değişkenlerin bağımlı değişken olan kahve dükkanlarını tercih etme niyeti üzerine etkisini incelemek amaciyla regresyon analizi gerçekleştirilmiştir. Gerçekleştirilen regresyon analizine ilişkin bulgular Tablo 7'de gösterilmiştir.

Tablo 7. Regresyon Analizine İlişkin Bulgular

\begin{tabular}{lccccc}
\hline Değişken & B & Std. Hata & B & t & p \\
\hline Sabit & 3,358 & 0,395 & - & 8,504 & 0,000 \\
1. Moda Tutkunları & 0,128 & 0,060 & 0,114 & 2,118 & $0,035^{*}$ \\
2. Yenilikçiler & 0,255 & 0,063 & 0,203 & 4,032 & $0,000^{*}$ \\
3. Becerikliler & $-0,178$ & 0,045 & $-0,197$ & $-3,990$ & $0,000^{*}$ \\
4. İlgi alanları Sinırlı Olanlar & $-0,095$ & 0,044 & $-0,103$ & $-2,010$ & $0,045^{*}$ \\
5. İnananlar & $-0,082$ & 0,041 & $-0,104$ & $-2,010$ & $0,035^{*}$ \\
\hline
\end{tabular}

Bağımlı değişken: Niyet

$\mathrm{R}=0,487 ; \mathrm{R}^{2}=0,237 ; \mathrm{F}=23,884 ; \mathrm{p}=0,000$

Kahve dükkanlarını tercih etme niyeti üzerinde etkisi olduğu düşünülen yaşam tarzının niyeti ne şekilde etkilediğine ilişkin gerçekleştirilen regresyon analizi sonucunda yaşam tarzı 
değişkenleri niyet üzerinde anlamlı bir etki $\left(R=0,487 ; R^{2}=0,237\right)$ gösterdiği görülmüştür. Söz konusu beş değişken kahve dükkanlarını tercih etme niyetinin \%24'ünü anlamlı bir şekilde açıklamaktadır. Moda tutkunları ve yeniliğe açık olanlar niyeti pozitif yönlü açıklamaktayken becerikliler, ilgi alanı sınırlı olanlar ve inananlar niyeti negatif yönlü açıklamaktadır. Bu bağlamda araştırma modelinde yer alan $\mathrm{H}_{1}, \mathrm{H}_{2}, \mathrm{H}_{3}, \mathrm{H}_{4}$ ve $\mathrm{H}_{5}$ hipotezleri kabul edilmiştir.

\section{SONUÇ ve ÖNERILER}

Yaşam tarzı, bireylerin kendilerini diğer bireylerden ayırt edebilmeleri için kullandıkları eylem ve tüketim kalıpları olarak belirtilmektedir (Karaca, 2018). Tüketicilerin satın alma davranışlarını belirlemede önemli bir faktör olan yaşam tarzı, tüketicilerin satın alma davranışını etkilerken aynı zamanda insanların boş zamanlarını değerlendirme faaliyetlerinde de farklılıklar oluşabilmektedir (Aydın ve Bakır, 2016). Küreselleşmenin kültürel ve ekonomik etkisiyle birlikte son yıllarda sayısında ciddi bir artış yaşayan ve 'kahve dükkanları' olarak adlandırılan mekânlar farklı yaşam tarzlarına sahip tüketicilerin tercih ettiği yerler olmaktadır.

Bu çalışmanın amacı tüketicilerin yaşam tarzının kahve dükkanlarını tercih etme niyeti üzerine etkisinin olup olmadığını incelemektir. Bu amaç çerçevesinde 390 katılımcıdan anket tekniği ile toplanan veriler ile gerçekleştirilen analizler sonucunda kahve dükkanlarını tercih etme niyeti üzerinde yaşam tarzının etkisine ilişkin bulgular saptanmıştır. Öncelikle katılımcıların kahve dükkanı alışkanlıklarına ilişkin özellikler incelenmiştir. Kahve dükkanlarını tercih eden tüketiciler genellikle kahve dükkanlarına haftada 1-2 defa gittiği ve kahve dükkanı türü olarak genellikle yerli kahve dükkanlarını tercih ettiği görülmüştür. Ayrıca kahve dükkanlarını tercih eden tüketiciler için kahve dükkanlarında sırasıyla arkadaşlarla buluşmak, aileyle vakit geçirmek ve yeme içme gereksinimlerini karşılamak önem taşımaktadır.

Tüketicilerin yaşam tarzlarının kahve dükkanları tercihi üzerine bir etkisinin olup olmadığı ortaya çıarılmaya çalışılmıştır. Gerçekleştirilen analizler sonucunda yaşam tarzı değişkenlerinin hepsinin kahve dükkanlarını tercih etme niyeti üzerinde anlamlı bir etkisinin olduğu saptanmıştır. Ancak; moda tutkunu ve yeniliğe açık olanların kahve dükkanlarını tercih etme niyeti üzerinde pozitif etkisi olduğu görünürken becerikliler, inanlar ve ilgi alanı kısıtlı olanların kahve dükkanlarını tercih etme niyeti üzerinde olumsuz etkisinin olduğu tespit edilmiştir.

Moda, tüketicilerin tercihleri üzerinde önemli bir etkiye sahip olmaktadır. Tüketiciler, tüketim kararlarında kişilik, statü ve öz kimlik gibi özelliklerinin öne çıkarılması için moda ürünlere veya hizmetlere yönelik hareket etmektedir (Ozansoy, 2009). Modernleşmeyle birlikte insanların talebi genellikle moda olana yönelme şeklinde olmaktadır. Modayı yakından takip eden, giyimine özen gösteren ve tanınmış markaları satın almaya dikkat eden moda tutkunu bireylerin kahve dükkanlarını tercih etme niyetinde oldukları belirlenmiştir. Kahve dükkanları tüketicileri kendilerini ifade etme biçimi ve toplumsal yaşamda bir statü göstergesi olarak görmektedir. Aşık'ta (2017) değişen kahve kültürünü dikkate aldığı çalışmasında kahve dükkanlarının genellikle gençler tarafından tercih edildiğini ve bu tercihin toplumsal yaşamda bir statü göstergesi olarak algılandığını belirtmektedir.

Yenilikçi tüketicilerin ürün veya hizmet satın almadaki en önemli özelliklerinden biri daha önce deneyimlemedikleri ürün ve hizmeti satın almaktır (Bekar ve Gövce, 2015). Typaldos (2016) küreselleşmenin kahve dükkanları üzerinde etkisini incelediği çalışmasında; kahve dükkanı tüketicilerinin sıra dışı bir kahve çeşidini deneyimlemek ve kahve dükkanının atmosferinin tadını çıkarmayı istediklerini belirtmektedir. Küresel ve yerelin etkileşimiyle kendine has yeme, içme, dinlenme ve sosyal faaliyet olanağı sunan kahve dükkanları (Bilge, 2010) yenilikçi yaşam 
tarzına sahip tüketicilerin sıklıkla tercih ettiği mekanlardır. Kahve dükkanları yalnızca yemeiçme gereksinimini karşılayan mekanlar olmayıp aynı zamanda farklı atmosferiyle tüketicilerin sıradan yaşam tarzlarına alternatif bir sosyal mekan olmaktadır. Yenilikçi yaşam tarzına sahip tüketiciler kahve dükkanlarını tercih ederken farklı atmosferleri deneyimlemek, daha önce tatmadıkları kahveleri içmek ve sosyalleşmek istedikleri düşünülmektedir.

Yaşam karşısında çeşitlilik ve yenilik arayanlar bireyler olduğu gibi rutin hayatı tercih edenler bireylerde bulunmaktadır (Saçlık, 2017). Tüketicilerin yaşam tarzlarının kahve dükkanlarını tercih etme niyeti üzerinde anlamlı ancak olumsuz etkisi olduğu saptanan becerikliler, ilgi alanları kısıtlı olanlar ve inanlar incelendiğinde bu üç yaşam tarzına sahip tüketicilerin genellikle rutin hayatı tercih eden bireyler olduğu görülmektedir. Becerikliler, kendi işlerini genellikle kendi halleden, yeni ürünlere kuşkuyla yaklaşan ve lüks tüketimden daha çok işine yarayacak ürünleri tercih eden bireylerdir (Erciş vd., 2007). Bu yaşam tarzına sahip bireylerin kahve dükkanlarını tercih etmeme nedenleri olarak, kahvelerini kendi evlerinde yapmak istemeleri ya da kahve dükkanlarını lüks tüketim mekanları olarak görmeleri şeklinde söylenebilir. Aynı zamanda bu yaşam tarzına sahip tüketicilerin para harcamaktan çok parayı kendi yararları doğrultusunda tutumlu kullandıkları düşünülmektedir.

Alı̧ılagelmiş tutum ve davranışlara sahip, geleneklere bağlı, muhafazakar bireyler olarak tanımlanan inanların kahve dükkanlarını tercih etmeme nedenleri ise şu şekilde ifade edilebilir. $\mathrm{Bu}$ yaşam tarzına sahip katılımcıların, aileleriyle evde zaman geçirmeyi seven, yeniliğe kapalı ve geleneklerine uygun ürünleri geleneklere uygun şekilde yapmayı tercih ettikleri düşünülmektedir. İlgi alanı kısıtlı yaşam tarzına sahip katılımcıların kahve dükkanlarını tercih etmeme nedenleri, bu katılımcıların genellikle içine kapanık olmaları, değişikliklere karşı ilgi duymamaları ve kendi halinde yaşamayı tercih etmeleri şeklinde ifade edilebilir.

Kahve dükkanlarını tercih etme niyeti açısından değerlendirildiğinde işletmelerin en uygun hedef kitleyi bulabilmek ve tüketicilere yönelik uygun stratejileri belirlemek için yaşam tarzını da dikkate almaları gerektiği düşünülmektedir. Kahve dükkanı sahibi veya yöneticisi sahip olduğu müşterinin yaşam tarzına yönelik özelliklerini daha iyi tanıyabileceği ve bu özelliklere göre hizmet kalitesini geliştirebileceği düşünülmektedir.

Çalışma, İstanbul'daki katılımcılardan elde edilen veriler ile gerçekleştirilmiştir. Bu bağlamda ileride yapılacak çalışmalar farklı ve geniş bir örneklem kullanılarak daha kapsamlı bir şekilde gerçekleştirilebilir. Ayrıca çalışmada yalnızca yaşam tarzının kahve dükkanları tercih etme niyeti üzerindeki etkisi incelenmiştir. İlerde yapılacak olan çalışmalar, başka değişkenleri de araştırma modeline ekleyerek bu çalışmanın bulgularını güçlendirebilir.

\section{KAYNAKÇA}

Acher, V. (2017). Life-Oriented Behavioral Research for Urban Policy. (Editör) Zhang, J. Japonya: Springer

Akarçay, E. (2012). Kah Kahvehane Kah Cafe: Küreselleşen Eskişehir'de Kahve Tüketimi Üzerine Kurumsal Bir Giriş, Galatasaray Üniversitesi İletişim Dergisi, 2: 182-202.

Aşık, N. A. (2017). Değişen Kahve Tüketim Alışkanlıkları ve Türk Kahvesi Üzerine Bir Araştırma, Journal of Tourism and Gastronomy Studies, 5(4): 310-325.

Aydın, G. A. ve Bakır, Z. N. (2016). Tüketim Kültürü Bağlamında Bir Mekân Değerlendirmesi Olarak Kahve Kafelerin Üniversite Öğrencileri Tarafından Tüketimi, Journal of Strategic Research in Social Science, 2(3): 59-84. 
Bayındır, B. (2018). Planlı Davranış Çerçevesinde Kahve Dükkanlarında Kahve İçme Davranışının İncelenmesi, Yayımlanmamış Yüksek Lisan Tezi, Akdeniz Üniversitesi, Antalya.

Bayındır, B. ve Önçel, S. (2019). Üniversite Öğrencilerinin Kahve Dükkânlarını Tercih Etme Nedenleri: Anadolu Üniversitesi Örneği, Journal of Tourism and Gastronomy Studies, 7(3): 18061820.

Bayındır, M. S. (2019). Gastronomi Turizmi. (Editör) Demir, Ş.: Turizmde Ürün Çeşitlendirme, İçinde, Ankara: Detay Yayıncılık.

Bekar, A. ve Gövce, A. M. (2015). Tüketicilerin Gıda Satın Alma Davranışları ile Yaşam Tarzı İlişkisi. Journal of International Social Research, 8(36).

Bookman, S. (2014). Brands and Urban Life: Specialty Coffee, Consumers, and The Co-Creation of Urban Cafe Sociality. Space and culture, 17(1): 85-99.

Brewer, R. (2015). Coffee Shops: Exploring Urban Sociability and Social Class in the Intersection of Public Private Space. Sociology/Anthropology Senior Thesis.

Bruwer, J. and Li, E. (2007). Wine-Related Lifestyle (WRL) Market Segmentation: Demographic and Behavioural Factors. Journal of Wine Research, 18(1): 19-34.

Bulut, E.T. (2019). Fast Food Ürünlerine Yönelik Tüketici Davranışları ile Yaşam Tarzı İlişkisi Üzerine Bir Araştırma: İzmir İli Örneği, Yayımlanmamış Yüksek Lisans Tezi, Ege Üniversitesi, İzmir.

Cătălin, M. C. and Andreea, P. (2014). Brands as A Mean of Consumer Self-Expression and Desired Personal Lifestyle, Procedia-Social and Behavioral Sciences, 109: 103-107.

Dedeoğlu, A. O. ve Üstündağlı, E. (2011). Sanal Topluluklar Bağlamında Tüketicilerin Tüketim, Yasam Tarzı Ve Kimlik Yönünden Değerlendirilmesi, Business and Economics Research Journal, 2(2): 23-40.

Demir, Ş. (2019). Gastronomi Turistlerinin Hedonik Tüketim ve Gönüllü Sade Yaşam Tarzı Davranışlarının Karşılaştırmalı Analizi. Yayımlanmamış Yüksek Lisans Tezi. Mersin Üniversitesi, Mersin.

Erciş, A., Ünal, S. ve Can, P. (2007). Yaşam Tarzlarının Satın Alma Karar Süreci Üzerindeki Rolü. Atatürk Üniversitesi İktisadi ve İdari Bilimler Dergisi, 21(2): 281-311.

Feria-Morales, A. M. (2002). Examining the Case of Green Coffee to Illustrate the Limitations of Grading Systems/Expert Tasters in Sensory Evaluation for Quality Control. Food Quality and Preference, 13(6): 355-367.

Filimonau, V., Krivcova, M. and Pettit, F. (2019). An Exploratory Study of Managerial Approaches to Food Waste Mitigation in Coffee Shops, International Journal of Hospitality Management, 76: 4857.

Hamşıŏlu, A. B. (2013). Fast Food Ürünleri Satın Alan Tüketicilerin Yaşam Tarzlarını Belirlemeye Yönelik Bir Uygulama, Uluslararası İktisadi ve İdari İncelemeler Dergisi, 6(11): 17-34.

Hu, X. and Lee, J. (2019). Emotions Elicited While Drinking Coffee: A Cross-Cultural Comparison Between Korean and Chinese Consumers. Food Quality and Preference, 76: 160-168.

Huang, L. V. (2017). Malaysian Café Culture: The Relationship Between Customer Experience and Customer Satisfaction Towards Contemporary Cafés. People: International Journal of Social Sciences, 3(2).

İslamoğlu, A. H. ve Altunışık, R. (2013). Tüketici Davranışları. İstanbul: Beta. 
Kabakçı, Ş. ve Madran, C. (2002). Tüketici Davranışını Etkileyen Bir Faktör Olarak Yaşam Tarzı: Çukurova Üniversitesinde Okuyan Kız Öğrencilerin Yaşam Tarzı Tiplerinin Belirlenmesine Yönelik Bir Araştırma, D.E.Ü.I.I.I.B.F. Dergisi, 17(1): 81-94.

Karaca, Ş. (2018). Yaşam Tarzının Sürdürülebilir Tüketim Davranışı Üzerindeki Etkisini Belirlemeye Yönelik Bir Çalışma, İşletme Araştırmaları Dergisi, 10(3): 403-425.

Kesiç, T. and Rajh S. P. (2003). Market Segmentation on The Basis Food Related Lifestyles of Croatian Families. British Food Journal, 105(3): 162-174.

Khraim, H.S. (2015), Segmentation of Young Consumers in Jordan in Terms of Their Lifestyle: An Exploratory Study, American Journal of Business and Management, 4 (1): 27-37.

Lee, H. S. and Yeu, M. S. (2010). Factors Influencing the Intention to Redeem Coffee Shop Coupons in Korea, International Journal of Business and Management, 5(7): 92-98.

Limón-Rivera, R., Mejía-Ochoa, F. J., Peláez-Muñoz, E. C., Vargas-Rivera, Y., HernándezVelásquez, S., Fierro-Domínguez, E. and González-Pérez, M. (2017). Analysis of the Relationship between Lifestyle and Coffee Consumption Habits, from the Myth Approach, in the Municipalities of Orizaba, Tehuipango, and Zongolica Veracruz, International Journal of Advanced Engineering, Management and Science, 3(12): 1111-1121.

Manzo, J. (2014). Machines, People, and Social Interaction in "Third-Wave" Coffeehouses. Journal of Arts and Humanities, 3(8): 1-12.

Oldenburg, R. (1989). The Great Good Place; Cafes, Coffee Shops, Bookstores, Bars, Hair Salons and Other Hangouts at the Heart of a Community. Da Capo Press, Cambridge.

Ozansoy, T. (2009). Moda Ürünlerinin Pazarlanmasında Sosyo-Psikolojik Faktörlerin Tüketici Tercihleri İle İlişkisi Üzerine Bir Pilot Araştırma. Yayımlanmamış Doktora Tezi. İstanbul Üniversitesi, İstanbul.

Özdemir, E. (2013). Yaşam Tarzının Kültür Turlarına Yönelik Algılar ve Tutumlar Üzerindeki Rolü. Yayımlanmamış Yüksek Lisans Tezi. Sakarya Üniversitesi, Sakarya.

Özdestan, Ö. (2014). Evaluation of Bioactive Amine and Mineral Levels in Turkish Coffee. Food research international, 61: 167-175.

Özgen, P. ve H. Yeşiloğlu. (2015). Organik Gıda Müşterilerinin Tüketim Davranışlarının Yaşam Tarzı Değişkeni Çerçevesinde İncelenmesi. Gazi Üniversitesi İ̈BF Dergisi, 197-215.

Ryan, I., Cowan, C., McCarthy, M., and O'sullivan, C. (2008). Segmenting Irish food consumers using the food-related lifestyle instrument. Journal of International Food $\mathcal{E}$ Agribusiness Marketing, 16(1): 89-114.

Saçılık, M. Y. (2017). Yaşam Tarzı, Çeşitlilik Arayışı İle Yiyecek İ̧cecek Tercihleri Arasındaki İlişki: Çeşitli Turist Grupları Üzerine Karşılaştırmalı Bir Araştırma. Yayımlanmamış Yüksek Lisans Tezi. 18 Mart Üniversitesi, Çanakkale.

Samoggia, A. and Riedel, B. (2018). Coffee Consumption and Purchasing Behavior Review: Insights for Further Research. Appetite, 129: 70-81.

Shaker, R. and Rath, J. (2019). The Coffee Scene in Glasgow's West End: on The Class Practices of The New Urban Middle Classes. City, Culture and Society, 17: 1-7.

Spence, C. and Carvalho, F. M. (2020). The Coffee Drinking Experience: Product Extrinsic (Atmospheric) Influences on Taste and Choice. Food Quality and Preference, 80: 103802. 
Tan, A. Y. and Lo, A. S. (2008). A Benefit-Based Approach to Market Segmentation: A Case Study of An American Specialty Coffeehouse Chain İn Hong Kong. Journal of Hospitality \& Tourism Research, 32(3): 342-362.

Tucker, M. C. (2011). Coffee Culture; Local Experiences, Global Connections. Routledge, New York.

Typaldos, C. (2016). Experiencing the Starbucks Experience-A Cultural Analysis of the Effects of Glocalization.

Uygun, M. (2016). Tüketicilerin Alışveriş Merkezi Deneyimlerinin Üçüncü Mekan Kuramı Çerçevesinde İncelenmesi. Aksaray Üniversitesi İktisadi ve İdari Bilimler Fakültesi Dergisi, 8(2): 122143.

Wei, C. C., Chiu, C. H., Wei, S. T. and Wei, C. S. (2019). Impact of Eight Dimensions on The Business of Specialty Coffee Shops. Research Journal of Business and Management, 6(1): 79-87.

Yıldırım, Y. (2016). Değerler Ve Yaşam Tarzının Tüketicilerin Ürün Tercihi Üzerindeki Rolü. Yayımlanmamış Yüksek Lisans Tezi. İnönü Üniversitesi, Malatya.

Yılmaz, B., Acar Tek, N. and Sözlü, S. (2017). Turkish Cultural Heritage: A Cup of Coffee. Journal of Ethnic Foods, 4(4): 213-220. 